
habits was not perceived by doctors as a priority. Many patients who drink to excess therefore remain unidentified and a major reducible cause of disease and death is ignored.

We thank the staff of York District Hospital for their cooperation in this work. The study was supported by a grant from the Health Promotion Research Trust; the opinions expressed are ours, not those of the trustees.

1 Lloyd G, Chick J, Crombie E, Anderson S. Problem drinkers in medical wards: consumption patterns and the disabilities in newly identified male cases. Br f Addict 1986;81:789-95.

2 Barrison IG, Viola L, Murray-Lyon IM. Do housemen take an adequate drinking history? BrMed $\mathcal{f}$ 1980;281:1040.

3 Babor TF, Ritson EB, Hodgson RJ. Alcohol related problems in the primary health care setting: a review of early intervention strategies. Br $\mathcal{F}$ Addict 1986;81:23-46.

4 Mayfield D, McLeod G, Hall P. The CAGE questionnaire: validation of a new alcoholism screening instrument. Am I Psychiatry 1974;131:1121-3.

5 Health Education Council. That's the limit. London: Health Education Council, 1986.

(Accepted 15 April 1987)

Centre for Health Economics, University of York, York YO1 5DD

N ROWLAND, BA, DIPCOUNS, research fellow

A MAYNARD, BA, BPHIL, professor of economics

Booth Park Hospital, York

A BEVERIDGE, MRCPSYCH, MPHIL, senior registrar in psychiatry

P KENNEDY, MD, FRCPSYCH, consultant psychiatrist

W WINTERSGILL, FFCM, MRCGP, community physician

District Hospital, York YO3 7HE

W STONE, FRCP, consultant physician

Correspondence to: Ms Rowland. detection. This study showed that questioning patients about their drinking

After the follicles had regressed a low dosage regimen of menotrophin was introduced using one ampoule (75 IU follicle stimulating hormone and $75 \mathrm{IU}$ luteinising hormone) daily and increasing by half an ampoule each week until a dominant follicle developed. On day 14 there was a single follicle $22 \mathrm{~mm}$ in diameter, and oestradiol concentration was $2340 \mathrm{pmol} / \mathrm{l}$. Human chorionic gonadotrophin $5000 \mathrm{IU}$ was given intramuscularly to provide a surge in luteinising hormone, and seven days later the progesterone concentration was $68 \mathrm{nmol} / \mathrm{l}$, suggesting ovulation. Ultrasound examination, however, showed hyperstimulation, with eight cysts $20-30 \mathrm{~mm}$ in diameter on the right ovary and four cysts on the left ovary. A similar regimen in the next cycle resulted in a single follicle $18 \mathrm{~mm}$ in diameter on day 14 ; this time no human chorionic gonadotrophin was given. Mid-luteal progesterone concentration was $11 \mathrm{nmol} / \mathrm{l}$, and the follicle regressed. Thus low dose menotrophin treatment induced normal follicular development but no spontaneous ovulation, and human chorionic gonadotrophin induced hyperstimulation.

Suppression of the persistently high luteinising hormone concentrations with a luteinising hormone releasing hormone agonist was attempted. Buserelin was given intranasally four times daily (total daily dose $1200 \mu \mathrm{g}$ ), and luteinising hormone, follicle stimulating hormone, and oestradiol concentrations were monitored. The table shows the rise in oestradiol concentration with initia stimulation and subsequent suppression of gonadotrophins and oestradiol. After one ampoule of menotrophin given intramuscularly each day for 10 days oestradiol concentration was $1840 \mathrm{pmol} / \mathrm{l}$ and two follicles, 17 and $20 \mathrm{~mm}$ in diameter, were seen on ultrasound examination. Human chorionic gonadotrophin $5000 \mathrm{IU}$ was given intramuscularly, but ultrasound examination confirmed failure of ovulation, with cyst formation (42 and $50 \mathrm{~mm}$ in diameter) and a progesterone concentration of $24 \mathrm{nmol} / \mathrm{l}$ associated with theca cell luteinisation. This regimen was repeated. On day 11 the oestradiol concentration was 1800 $\mathrm{pmol} / \mathrm{l}$, and ultrasound examination showed one follicle $18 \mathrm{~mm}$ in diameter and three follicles $10-12 \mathrm{~mm}$ in diameter. Human chorionic gonadotrophin $7500 \mathrm{IU}$ was given intramuscularly, and seven days later the progesterone concentration was very high (>100 nmol/l), suggesting conception. Buserelin was withdrawn and a singleton pregnancy was confirmed on ultrasound examination. At the time of writing the pregnancy had reached 30 weeks gestation and was progressing normally.

Concentrations of oestradiol, follicle stimulating hormone, and luteinising hormone before and after treatment with buserelin

\section{Successful treatment of infertility due to polycystic ovary disease using a combination of luteinising hormone releasing hormone agonist and low dosage menotrophin}

Infertility and early loss of pregnancy in women with polycystic ovary disease may be caused by excessively high concentrations of luteinising hormone during follicular development. ${ }^{1}$ Different regimens have been suggested to improve the poor outlook for these patients, ${ }^{2}$ including the use of "pure" follicle stimulating hormone (Metrodin) ${ }^{3}$ and suppression of endogenous luteinising hormone production by treatment with a luteinising hormone releasing hormone agonist before stimulation of the ovaries. ${ }^{4}$ Luteinising hormone releasing hormone agonists, given continuously rather than cyclically, reduce gonadotrophin concentrations to prepubertal values. We describe the successful treatment of a patient with polycystic ovary disease and primary infertility of five years duration using a "block and replace" approach.

\section{Case report}

A woman started taking the contraceptive pill at the age of 18 because of irregular menstrual cycles and menorrhagia and stopped taking it at the age of 23 because she wished to become pregnant. Her cycles were irregular for 18 months, and a gynaecological opinion was sought. Examination showed that she was slim and non-hirsute. Investigations showed a testosterone concentration of $6.0 \mathrm{nmol} / 1$ (normal range in women $<2.5 \mathrm{nmol} / \mathrm{l}$ ), and luteinising hormone was raised throughout the menstrual cycle $(37,45,>50,24,>50$ IU/1); Prolactin concentration was normal, but serial mid-luteal progesterone was $<3 \mathrm{nmol} /$, confirming non-ovulatory cycles. Clomiphene citrate $50 \mathrm{mg}$ taken on days 2-6 induced regular cycles, but persistently low progesterone values showed that they were non-ovulatory.

Ultrasound examination showed the classic appearance of polycystic ovaries, which were confirmed histologically. Laparoscopy and injection of dye showed that the uterus and fallopian tubes were normal. Clomiphene citrate $100 \mathrm{mg}$ taken on days 2-6 induced an increase in oestradiol concentration to $830 \mathrm{pmol} / \mathrm{l}$ with a dominant follicle $17 \mathrm{~mm}$ in diameter; however, mid-luteal progesterone concentration remained poor at $15 \mathrm{nmol} / \mathrm{l}$, despite intramuscular injection of human chorionic gonadotrophin $10000 \mathrm{IU}$. Treatment with menotrophin (Pergonal), as directed by the manufacturers, was started, but after three ampoules (225 IU follicle stimulating hormone and 225 IU luteinising hormone) on days 3,5 , and 7 oestradiol concentration rose to $2760 \mathrm{nmol} / 1$. Ultrasound examination confirmed moderate hyperstimulation with three to four follicles in each ovary.

\begin{tabular}{lccc}
\hline & $\begin{array}{c}\text { Oestradiol } \\
\text { (pmol/l) }\end{array}$ & $\begin{array}{c}\text { Follicle stimulating } \\
\text { hormone } \\
\text { (IU/l) }\end{array}$ & $\begin{array}{c}\text { Luteinising } \\
\text { hormone } \\
\text { (IU/I) }\end{array}$ \\
\hline $\begin{array}{l}\text { Before treatment with buserelin } \\
\text { After treatment with buserelin: }\end{array}$ & 170 & $5 \cdot 3$ & 37 \\
1 week & 450 & $2 \cdot 9$ & 26 \\
2 weeks & 880 & $0 \cdot 7$ & $7 \cdot 1$ \\
3 weeks & 70 & $0 \cdot 8$ & $3 \cdot 2$ \\
6 weeks & 80 & $3 \cdot 2$ & $2 \cdot 0$ \\
\hline
\end{tabular}

\section{Comment}

Our patient's treatment was hampered by her tendency to hyperstimulate with pronounced cyst formation, probably related to her persistently raised luteinising hormone concentration. The combination of suppression of endogenous luteinising hormone production and low dose menotrophin treatment resulted in conception in the second cycle of treatment. This regimen, or one using a long acting luteinising hormone releasing hormone analogue ${ }^{5}$ may be helpful in other patients with polycystic ovary disease.

1 Howles CM, Macnamee CM, Edwards RG, Goswamy R, Steptoe PC. Effect of high tonic levels of luteinising hormone on outcome of in-vitro fertilisation. Lancet 1986; ;i:521-2.

2 Franks S, Adams J, Mason H, Polson D. Ovulatory disorders in women with polycystic ovary syndrome. Clin Obstet Gynaecol 1985;12:605-32.

3 Ginsburg J, Sallam H, Scammell G, et al. Ovulation and pregnancy after pure FSH therapy in sclerocystic ovarian change. In: Ludwig G, Thompson K, eds. Archives of gynaecologv. Berlin: Springer Verlag, 1986 oligomenorrhoea using a combination of an LHRH agonist and exogenous gonadotrophins. Brf Obstet Gynaecol 1985;92:369-73.

5 Thomas EJ, Jenkins J, Lenton EA, Cooke ID. Endocrine effects of goserilin, a new depot luteinising hormone releasing hormone agonist. Br Med f 1986;293:1407-8.

(Accepted 9 April 1987)

Endocrine Section, Department of Medicine II, Southampton General Hospital, Southampton SO9 4XY

MARY ARMITAGE, BSC, MRCP, senior registrar

TERENCE WILKIN, MD, MRCP, senior lecturer

Department of Radiology, Southampton General Hospital, Southampton SO9 4XY

KEITH DEWBURY, FRCR, MB, consultant radiologist

Correspondence to: Dr Mary Armitage, Medicine II, Level D, South Block Southampton General Hospital, Southampton SO9 4XY.
4 Fleming R, Haxon MJ, Hamilton MPR, et al. Successful treatment of infertile women with 